\title{
Biological Modulation of Parp Inhibition in Triple Negative Breast Cancer, a Combinational Approach Implementing Multitargeted Epigenetic Therapy (Mtet) with Parp Inhibition, in Advanced Breast Cancer: A Case Study
}

\author{
M. Nezami, Steve Hager, Julie Taguchi \\ Pacific Medical Center of Hope, Fresno, USA \\ Email: amnezami@yahoo.com
}

How to cite this paper: Nezami, M., Hager, S. and Taguchi, J. (2018) Biological Modulation of Parp Inhibition in Triple Negative Breast Cancer, a Combinational Approach Implementing Multitargeted Epigenetic Therapy (Mtet) with Parp Inhibition, in Advanced Breast Cancer: A Case Study. Journal of Cancer Therapy, 9, 729-739. https://doi.org/10.4236/jct.2018.99060

Received: August 19, 2018

Accepted: September 8, 2018

Published: September 11, 2018

Copyright $\odot 2018$ by authors and Scientific Research Publishing Inc. This work is licensed under the Creative Commons Attribution International License (CC BY 4.0).

http://creativecommons.org/licenses/by/4.0/

\begin{abstract}
The introduction of PARP inhibitors as active agents to inhibit the DNA repair was a revolution in the cancer therapeutics, however, such approach only has shown promising results for a short time in majority of cases due to secondary mutations and promoter gene methylation, and most of patients with triple negative breast cancer when treated with such agents only benefit for a short time, until the tumor shows resistance and further the therapy fails [1]. Considering this category of drugs and their mechanism of action in DNA repair [2] [3], several recent studies have focused on combination of PARP inhibitors with chemotherapy, immune therapy and interestingly relevant to this article, epigenetic therapies [4]. That said, to our knowledge the human data in this regard is missing. Here we discuss a case report of a patient with stage four refractory and resistant BRCA1 mutated triple negative breast cancer who responded in matter of two weeks to a combinational therapy, consisting of PARP inhibitor and epigenetic therapies. As the patient already had exhausted the PARP inhibitor by excessive presence of BRCA positive altered circulatory DNA, the response merely reflects the epigenetic therapy as back bone of treatment. The liquid biopsy repeated after two weeks of combination therapy showed complete disappearance (resolution of positive BRCA gene/c DNA), reflecting a synergism by proposed modulation of resistance as mechanism of action. (The initial c DNA showed 93 percent mutation allele fraction of BRCA gene.) To our knowledge, this is the first study on combinational therapy in human. The finding in this case could potentially change the standard of care in treating BRCA positive tumors, by providing a superior treatment to current standards.
\end{abstract}




\section{Keywords}

Triple Negative Breast Cancer, PARP Inhibition, Epigenetic Therapies

\section{Background}

Triple negative breast cancers compromise about $15 \%$ of breast cancers overall, about $70 \%$ of breast cancers in individuals harboring a germline BRCA1 mutation, and $20 \%$ in BRCA2 mutation carriers, vice versa, the presence of germ line and/or somatic mutations in BRCA has been widely recognized in triple negative breast cancer. As of January 2016, there were more than 6 PARP inhibitors under development for BRCA positive tumors (See Table 1).

That said, a common failure of phase III trials has been improved progression free or more importantly the overall survival in the group of patients with triple negative breast cancer treated with single PARP inhibitors. A good example of this is phase III trial using Inaparib in patients with triple negative breast cancer who also received cytotoxic chemotherapy and showed no improvement in survival (phase II trial however showed promising results). A common rationale on the failure of the drug is the epigenetic aberrancies involving the BRCA gene and acquired resistance explained by secondary mutations.

In Oct., 2016, the preclinical work of Dr. Baylin at John Hopkins showed that PARP inhibitors work according to how intensely and durably the PARP

Table 1. List of all PARP inhibitors.

\begin{tabular}{|c|c|c|}
\hline $\begin{array}{c}\text { Olaparib } \\
(\mathrm{AZD} 2281)\end{array}$ & Astra Zeneca & $\begin{array}{l}\text { Phase } 3 \text { studies in adjuvant and advanced settings in } \\
\text { germline BRCAm breast cancer }\end{array}$ \\
\hline $\begin{array}{l}\text { Veliparib } \\
(\text { ABT-888) }\end{array}$ & Abbvie & $\begin{array}{l}\text { Phase } 3 \text { study in neoadjuvant setting in combination with } \\
\text { carboplatin and standard therapy in triple-negative breast cancer } \\
\text { Phase } 2 / 3 \text { studies in advanced setting as combination } \\
\text { therapy in germline BRCAm breast cancer }\end{array}$ \\
\hline $\begin{array}{l}\text { Niraparib } \\
\text { (formerly } \\
\text { MK-4827) }\end{array}$ & Tesaro & $\begin{array}{l}\text { Phase } 3 \text { study in advanced setting in germline BRCAm } \\
\text { breast cancer }\end{array}$ \\
\hline \multirow{4}{*}{$\begin{array}{l}\text { Talazoparib } \\
(\mathrm{BMN}-673)\end{array}$} & \multirow{4}{*}{$\begin{array}{c}\text { BioMarin } \\
\text { Pharmaceuticals }\end{array}$} & $\begin{array}{l}\text { Phase } 3 \text { study in advanced setting in germline BRCAm } \\
\text { breast cancer }\end{array}$ \\
\hline & & Phase 2 studies in advanced setting in BRCAm breast cancer \\
\hline & & $\begin{array}{l}\text { Phase } 2 \text { study in advanced setting in germline BRCA } \\
\text { intact breast cancer }\end{array}$ \\
\hline & & Phase 2 study in neoadjuvant setting in BRCAm breast cancer \\
\hline $\begin{array}{l}\text { Rucaparib } \\
\text { (formerly } \\
\text { AG-14699) }\end{array}$ & $\begin{array}{l}\text { Clovis } \\
\text { Oncology }\end{array}$ & $\begin{array}{l}\text { Phase } 2 \text { study in advanced setting in patients with } \\
\text { known germline BRCAm solid tumors } \\
\text { Phase } 2 \text { study in adjuvant setting in triple-negative } \\
\text { breast cancer or germline BRCAm breast cancer }\end{array}$ \\
\hline CEP-9722 & $\begin{array}{c}\text { Teva } \\
\text { Pharmaceutical } \\
\text { Industries }\end{array}$ & Phase 2 study in advanced setting in solid tumors \\
\hline
\end{tabular}


enzyme is trapped at certain DNA damage sites. Therefore, by ramping up the duration and intensity of this trapping, you could potentially increase the efficacy of the drug. Such understanding provides the rationale on combination of epigenetic therapies with PARP inhibitors [5] [6]. That said, to our knowledge, the combination of epigenetic therapies consisting of the protocol we used with a known PARP inhibitor has never been clinically explored in an advanced case of triple negative breast cancer and clinical relevance been discussed.

\section{Methods}

Epigenetic therapies, consisting of polyphenol, Quercetin as mainstay of therapy, and phenyl butyrate, in a protocol called "multitargeted epigenetic therapies" administered intravenously on daily basis.

\section{Case Report}

$37 \mathrm{yr}$ female w/metastatic breast ca to bone, lymph nodes, and brain, she was Caucasian, had positive family history for maternal breast cancer, and was non smoker.

Patient was initially diagnosed in July 2013 w/stage III right breast ca and 4 axilla lymph nodes. BRCA $1 \mathrm{w} /$ Met ER+. Pt received 4 cycles of ATC, then underwent double mastectomy, followed by 36 rounds of radiation therapy, and then prophylactic oophorectomy.

In June 2015, CA27/29 marker noted to be elevated and scans indicated mets to left lung and left clavicle lymph nodes. Pt participated in UCLA trial w/PARP inhibitor from July to October 2015. Then switched to Xeloda from Nov. 2015 to Jan. 2016. From Feb. to March 2016 patient was on Aromatase inhibitor and Ibrance. From April to May 2016 patient received Carbo/Gemzar but during this time period patient developed pain in sacrum. In June 2016, she received radiation to sacrum with relief of pain and also received radiation to two brain lesions per cyberknife. In July to Aug. 2016 participated in Stanford trial BMO1103 and received more radiation to another brain lesion.

She also received 10 rounds of radiation to lesions noted on neck. In Oct. 2016, patient started immunotherapy, PARP, and Ameridex. Her restaging PET scan showed very large mass in the left lower lung, as well as severe lymphadenopathies in her neck, thorax and pelvis, retroperitoneum with mass effect on IVC, causing hydronephrosis and partial colon obstruction, due to peritoneal carcinomatosis, along with sacrum large lesion with significant uptake, compared to her PET scan in 5/15 (see Image 1).

She was referred by her oncologist to us for evaluation and treatments. On her initial evaluation, she was in significant pain. Labs indicated 93 percent MAF of c DNA with several alterations, including BRCA. CTC was positive for three out of four markers, very extensively high.

Immediately after starting the multi targeted epigenetic therapies (MTET), she was feeling better and breathing better and had more sense of well being after 


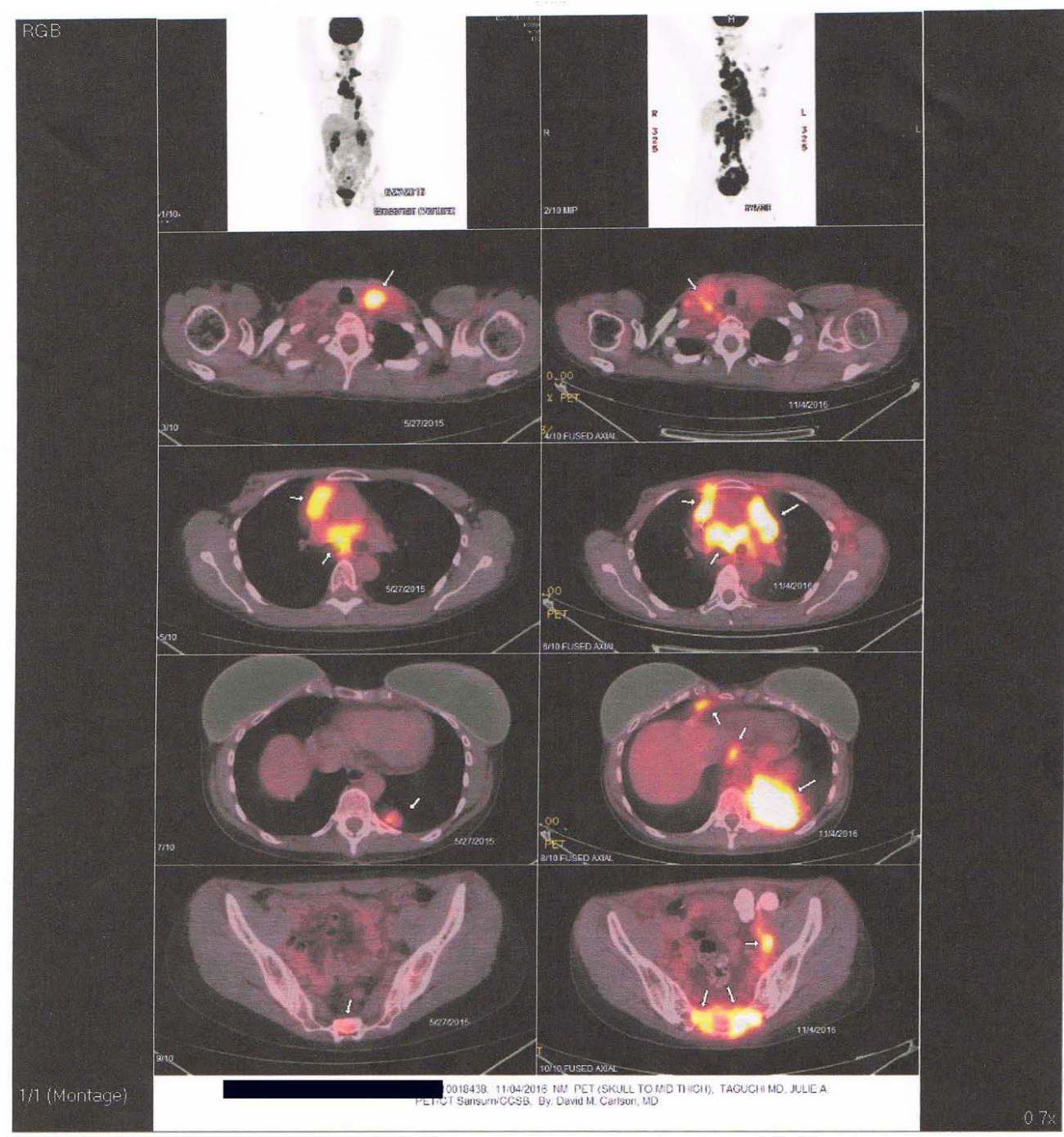

\section{Attachments}

- image001.png (647.50KB)

out:blank

Image 1. Whole body PET scan

the first two treatments. Pain was better. Less nauseous. More appetite. She did not experience any toxicity from the treatment.

Lab showed significant reduction in her tumor markers (CA 27.29 and CA 15.3) and $\mathrm{LDH}$, measured on $11 / 22 / 16$, compared to $11 / 7 / 16$.

CA 15.3 at 179 from 249. LDH down from 1603 to 1348 and further down to 1298 (measured on 12/6/16) and 890 two weeks after. After two weeks of therapy all her CTC markers dropped including the CK19, telomerase, ERBB2 and c Myc. 


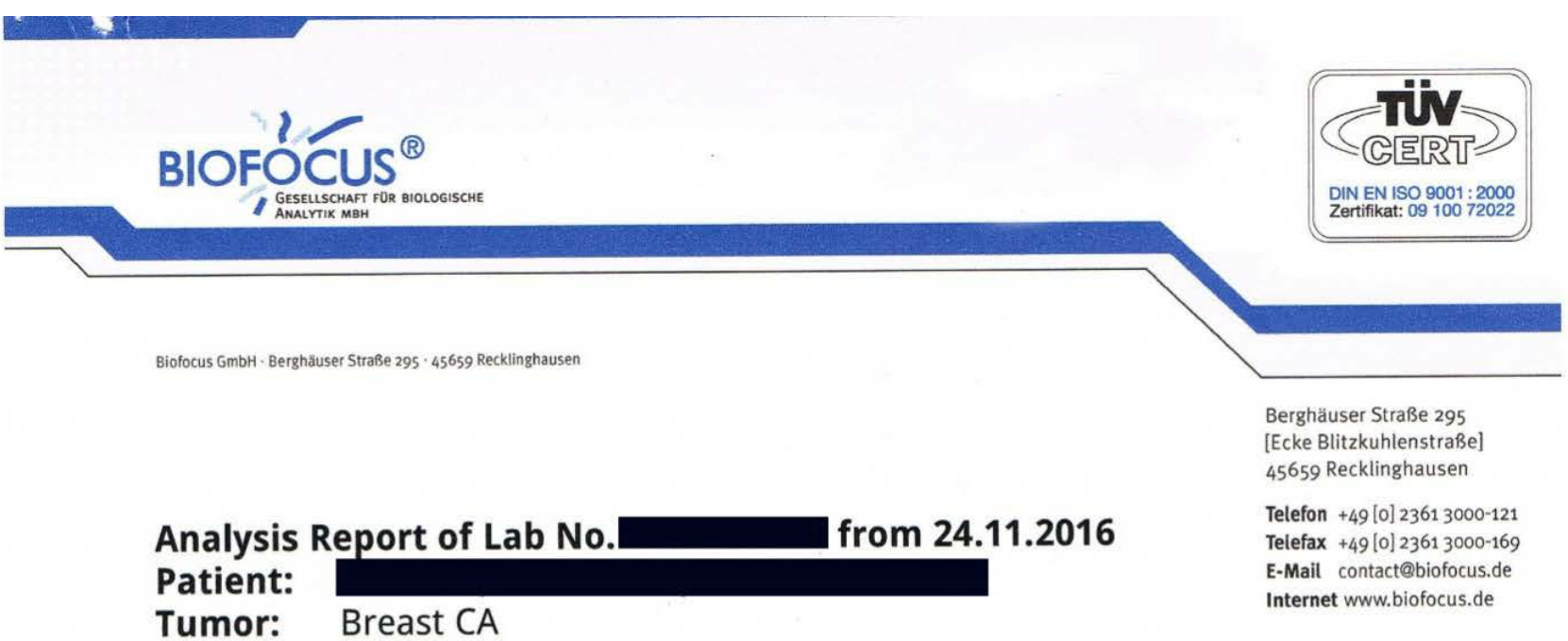

For the analysis, we performed the following work steps

\section{Isolation of circulating tumor cells / micrometastases}

In order to obtain circulating tumor cells from the patient's peripheral blood, large cells and cellclusters as well as epithelial cells were isolated. A preparation of mononuclear cells (MNC) served as a control cell fraction. From all fractions mRNA was isolated. Afterwards, the expression of tumorrelevant genes was measured by quantitative real-time RT-PCR.

\section{Molecular detection of circulating tumor cells}

\begin{tabular}{|l|l|}
\hline \multicolumn{2}{|l|}{ The following molecular markers were used to detect tumor cells: } \\
\hline Telomerase & $\begin{array}{l}\text { The expression of the telomerase-gene can be increased in most tumor types, but } \\
\text { not in normal tissue. An increased expression of the telomerase gene may be } \\
\text { indicative for the presence of tumor cells in the circulation. } \\
\text { pos: Overexpression of telomerase was detected in the isolated cells. }\end{array}$ \\
\hline C-MYC & $\begin{array}{l}\text { Overexpression of C-MYC indicates an increased proliferation-rate of the isolated } \\
\text { cells. An increased proliferation-rate is a typical feature of tumor cells. } \\
\text { pos: The expression level of C-MYC was elevated. }\end{array}$ \\
\hline ERBB2 & $\begin{array}{l}\text { Overexpression of ERBB2 (HER2/NEU) is a trait of different types of cancers and may } \\
\text { be observed also in breast cancer. Thus, the detection of ERBB2 overexpression may } \\
\text { be indicative for the presence of circulating tumor cells. } \\
\text { pos: Expression of ERBB2 was elevated. }\end{array}$ \\
\hline CK19 & $\begin{array}{l}\text { The detection of an expression of the cytokeratin 19 (CK19) gene indicates the } \\
\text { presence of epithelial cells and may thus be indicative for circulating tumor cells. } \\
\text { pos: There was strong expression of CK19 detected. }\end{array}$ \\
\hline
\end{tabular}

\section{Interpretation}

In the isolated tumor cell fraction, expression of ERBB2, C-MYC and telomerase was above threshold $(>2.0)$ and expression of CK19 was above threshold $(>0)$ in the very high range $(>10000)$. This finding may indicate the presence of circulating tumor cells in the analysed blood sample.

Bankverbindung

HypoVereinsbank Essen · BLZ 36020186 . Konto 321003010

IBAN DE39 $360201860321003010 \cdot$ BIC HYVEDEMM360
Amtsgericht Recklinghausen HRB 2611

USt.-Id.-Nr. DE 126341217

St.-Nr. 34057054286 


\section{3. comparison of present findings with former results}

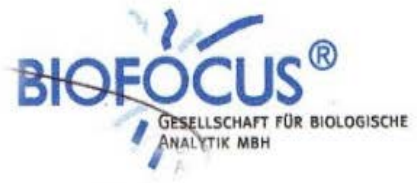

Compared to the former analysis from-9-Nov-2016, the expression levels of the molecular tumor markers CK19, C-MYC, ERBB2 and telomerase have significantly decreased but are still elevated in the higher range.

\begin{tabular}{|c|c|c|c|c|}
\hline $\begin{array}{l}\text { Marker } \\
\text { (threshold) }\end{array}$ & $\begin{array}{l}\text { ERBB2 } \\
(2.0)\end{array}$ & $\begin{array}{l}\text { C-MYC } \\
(2.0)\end{array}$ & $\begin{array}{l}\text { Telomerase } \\
(2.0)\end{array}$ & 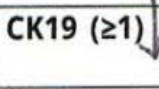 \\
\hline 24.11 .2016 & 12,35 & 3,15 & 19,1 & $18818 \mathrm{ceq}$ \\
\hline 09.11 .2016 & 27,8 & 5,65 & 49,6 & $47735 \mathrm{ceq}$ \\
\hline
\end{tabular}

*markers above threshold in bold face, ceq=cell equivalents

\section{Conclusion:}

The measured values of the detection markers suggest that the tumor cell burden in blood has decreased compared to the former analysis.

Figure 1. Circulating tumor cells.

This happened without using any chemotherapy (please see Figure 1).

Her circulatory DNA through Guardant dropped from 93 percent on BRCA to non detectable (See Figure 2). This substantial response confirms the synergistic effect of the applied combinational therapy, and noticed in only 14 days after the initiation of the therapy.

Further the PARP inhibitor was stopped and the polyphenol therapy was continued. The c DNA was repeated on 12/20/16 and it showed increased BRCA back up again at 86 percent (please see Figure 3).

Patient accomplished unexpected response to the combinational therapy of PARP inhibitors and epigenetic protocol, with improved progression free survival and quality of life. She was under our care for three months and did not encounter any toxicity form the therapy.

\section{Conclusion}

Application of dual inhibition of epigenetic modifier consisting of natural compounds implemented in multitargeted epigenetic therapy (MTET) and traditional PARP inhibition is feasible and clinically relevant. Such therapy in our study showed significantly effective in treating BRCA positive colonies in tumor in triple negative breast cancer. The correlation of liquid biopsy findings and clinical response to such combinational therapy is also important as it can be used as a companion diagnostic for the therapy. We conclude that such therapy could replace the current standard of care in advanced triple negative breast cancer harboring BRCA deficient somatic or germ line mutations. 


$\begin{array}{ll}\text { Patient } & \text { Reporting } \\ & \text { REPORT DATE } \\ - & \text { DEC-10-2016 } \\ \text { GENDER } & \text { RECEIPT DATE } \\ \text { Female } & \text { NOV-23-2016 } \\ \text { CUNICAL DIAGNOSIS } & \text { COUECTION DATE } \\ \text { Breast Carcinoma } & \text { NOV-22-2016 } \\ & \text { SPECIMEN } \\ & \text { Blood }\end{array}$

Physician

NAME

Mohammed Amin Nezami

ACCOUNT

Orange Coast Medical Center of Hope 496 Old Newport Blvd Ste 7, Newport Beach, CA 92663

PHONE

$\begin{array}{ll}\text { (949) } 515-4673 & \text { (559) } 439-5828\end{array}$

ADDTIONAL RECIPIENT
Biopsy-Free TM Tumor Sequenci

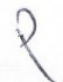

Guardant360 Tumor Response Map

The Guardant360 Tumor Response Map illustrates the mutant allele percentage (\% cfDNA) of observed somatic variants at each sample submission time point. The "Somatic Alteration Burden" value below refers to the maximum \% cfDNA detected at each time point. Amplifications are not plotted, and only the first and last four test dates are plotted. Please see the Physician Portal (https://portal.guardanthealth.com) for the Tumor Response Map with all test dates.

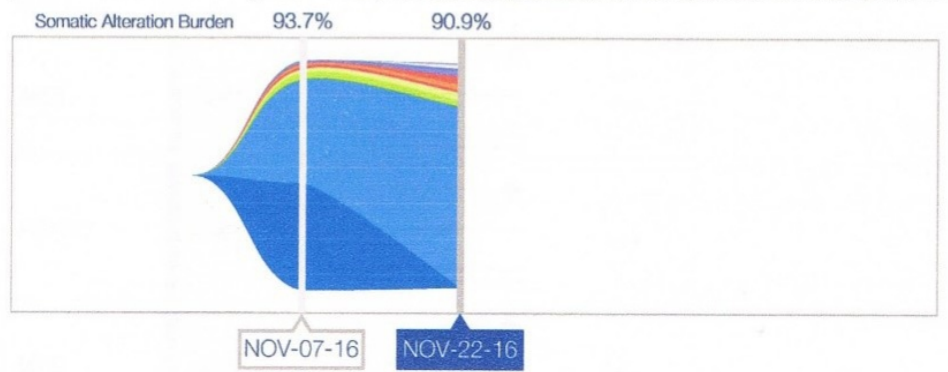

17 Total Somatic Alteration(s) Detected

9 with Associated Therapy

0 Associated with Lack of Response

Multiple Clinical Trials Available

Summary of Somatic Alterations \& Associated Treatment Options

The percentage of altered cell-free DNA (\% cfDNA) circulating in blood is related to the unique tumor biology of each patient. Factors that may affect the $\%$ cfDNA of detected somatic alterations include tumor growth, turn-over, size, heterogeneity, vascularization, disease progression, and treatment.

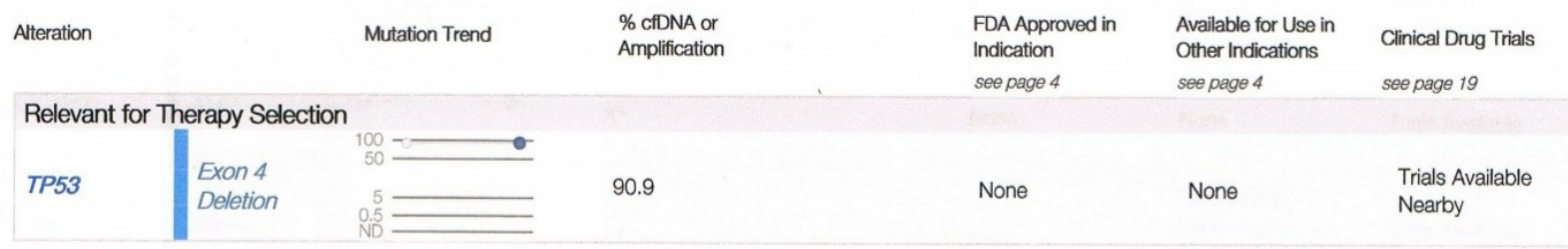

GUARDANTHEALTH For a more detailed Guardant360 Patient Report, log onto: https://portal.quardanthealth.com or to set up an account, contact Client Services: 855.698 .8887 


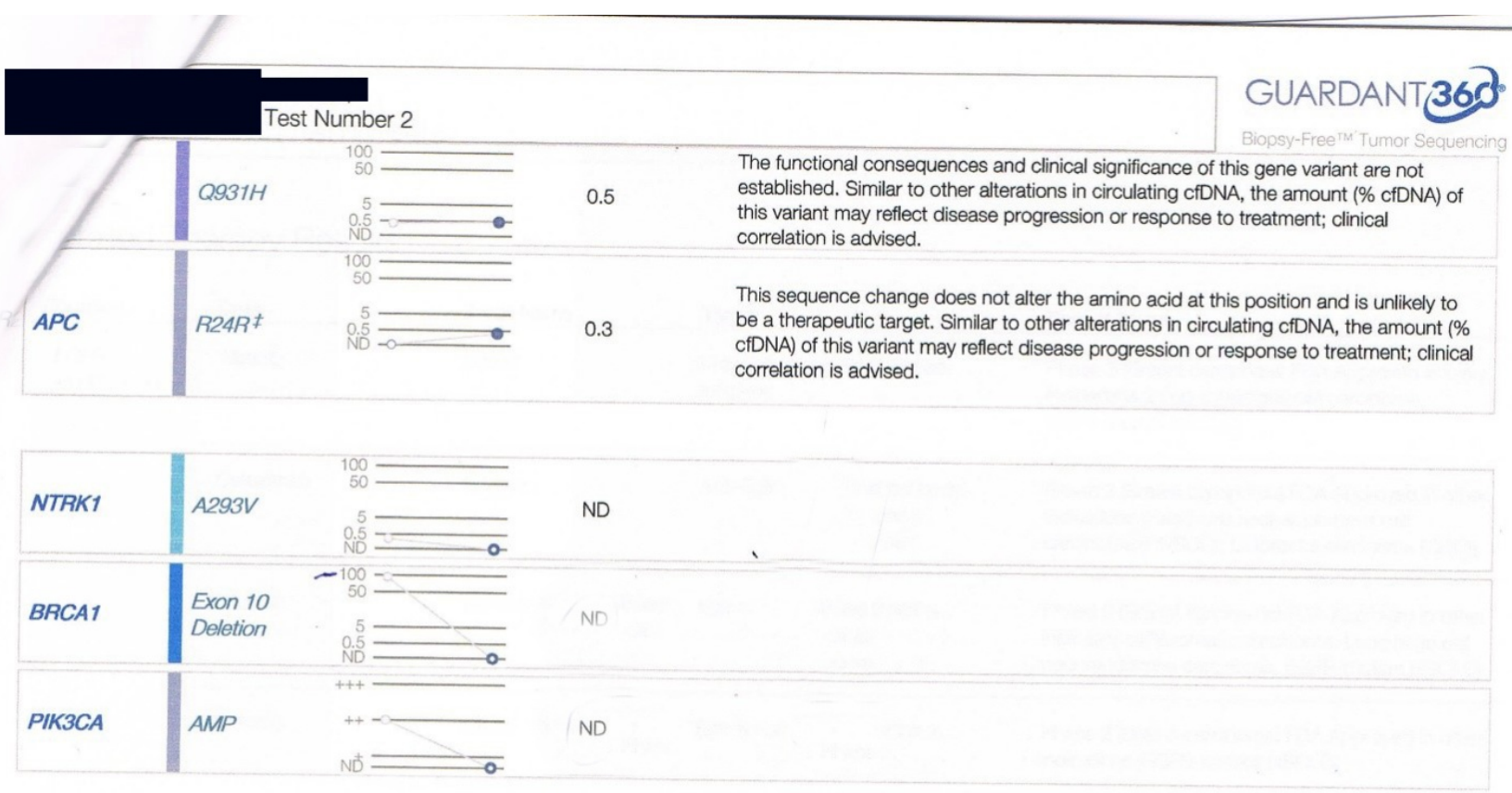

The chart above annotates the allele frequency of altered circulating cell-free DNA (\% cfDNA) detected in this patient. Alterations are listed in descending order of \% cfDNA by
gene.

All therapeutic annotations are based on publicly available information as described in the "Detailed Therapy Results" and "Clinical Relevance of Detected Alterations" sections of the report.

Genomic Alterations: Not Detected (ND). Genomic alterations may be present that are below the limit of detection of this test. Certain sample or variant characteristics may free DNA from this blood specimen with this test.

$¥$ Synonymous mutations and Variants of Uncertain Significance (VUSs): The functional consequences and clinical significance of this gene variant are not established. Similar to other alterations in circulating cfDNA, the amount (\% cfDNA) of this variant may reflect disease progression or response to treatment; clinical correlation is advised.

\section{Definitions}

Amplification: Gene amplification results in increased copies of the gene present in the cfDNA. As the absolute number of copies in circulation is dependent on both tumor fraction and the magnitude of the tumor amplification, amplifications are reported on a semi-quantitative scale: Positive (+): amplification magnitude is in the lower 50 th percentile of samples with amplifications; Strongly Positive (++): amplification magnitude is in the 50th to 90th percentile; Very Strongly Positive (+++): amplification magnitude is in the top 10 th percentile. Guardant 360 detects amplifications in the genes listed in Table 1.

Deletion (Del): The following alteration was detected in this patient: TP53 Y103fs; BRCA1 L666fs, R664fs, K690fs, S681fs. Guardant360 detects short deletions in exons of certain genes (see Table 1), including potential splice site-disrupting events.

Comments

$$
\text { None. }
$$

Interpretation

Somatic alterations were detected in the circulating cell-free DNA isolated from this patient's blood specimen. These genomic alterations are cancer-associated somatic variants, some of which have been associated with either increased or reduced clinical response to specific treatments.

Amplification was detected in the circulating cell-free DNA isolated from this patient's blood specimen for the annotated gene(s). Unlike tissue-based gene amplification tests (e.g. IHC or FISH), Guardant360 assesses the total representation of a given gene in all circulating cell-free DNA present in the patient's blood sample including material derived from the tumor and healthy tissue alike. As such, the absolute level of amplification present in the blood depends both on the tumor-derived cfDNA content and on the of cells with extremely high levels of the and cannot be inferred from bulk cfDNA interrogation. For example, a positive Guardant360 test could represent a small population amplifications. The exact correlation the detected gene amplification. Alternatively, it could represent a large population of cells with low to medium levels of the detected gene amplifications. The exact correlation between amplification detected by Guardant 360 compared to IHC or FISH and how each test differentially guides patient management is

For a more detailed Guardant360 Patient Report, log onto: https:/portal Guardantheath.cOm or to $\quad$ GUALTH

Figure 2. Circulating DNA (11/22/2016). 
Patient

MRN

GENDER

Female

CLINICAL DIAGNOSIS

Breast Carcinoma

\section{Reporting}

REPORT DATE JAN-10-2017

RECEPT DATE DEC-21-2016

COUECTION DATE

DEC-20-2016

SPECIMEN

Blood
Physician

NAME

Mohammed Amin Nezami

ACCOUNT

Orange Coast Medical Center of Hope

496 Old Newport Blvd Ste 7, Newport Beach, CA 92663

PHONE

(949) $515-4673$

ADDIIONAL RECIPIENT

Blood ADDIONAL RECIPIENT
-

Guardant360 Tumor Response Map

The Guardant360 Tumor Response Map illustrates the mutant allele percentage (\% cfDNA) of observed somatic variants at each sample submission time point. The "Somatic Alteration Burden" value below refers to the maximum \% cfDNA detected at each time point. Amplifications are not plotted, and only the first and last four test dates are plotted. Please see the Physician Portal (https://portal.guardanthealth.com) for the Tumor Response Map with all test dates.

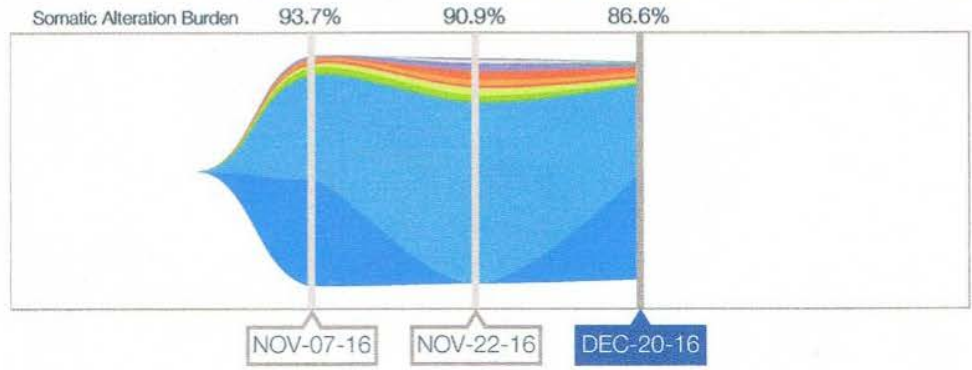

\section{Total Somatic Alteration(s) Detected}

10 with Associated Therapy

0 Associated with Lack of Response

Multiple Clinical Trials Available

Summary of Somatic Alterations \& Associated Treatment Options

The percentage of altered cell-free DNA (\% cfDNA) circulating in blood is related to the unique tumor biology of each patient. Factors that may affect the \% cfDNA of detected somatic alterations include tumor growth, turn-over, size, heterogeneity, vascularization, disease progression, and treatment:

Alteration

Mutation Trend

\section{$\%$ cfDNA or}

FDA Approved in

Indication

Available for Use in

see page 4

Other Indications

Clinical Drug Trials

see page 20

GUARDANT HEALTH

For a more detailed Guardant360 Patient Report, log onto: https://portal.guardanthealth.com or to set up an account, contact Client Services: 855.698 .8887

Arthur Baca, MD PhD Laboratory Director | CLIA ID: 05D2070300 | 505 Penobscot Drive, Redwood City, CA 94063 TST-PRT-001 V15.0 | Pg 1 of 43




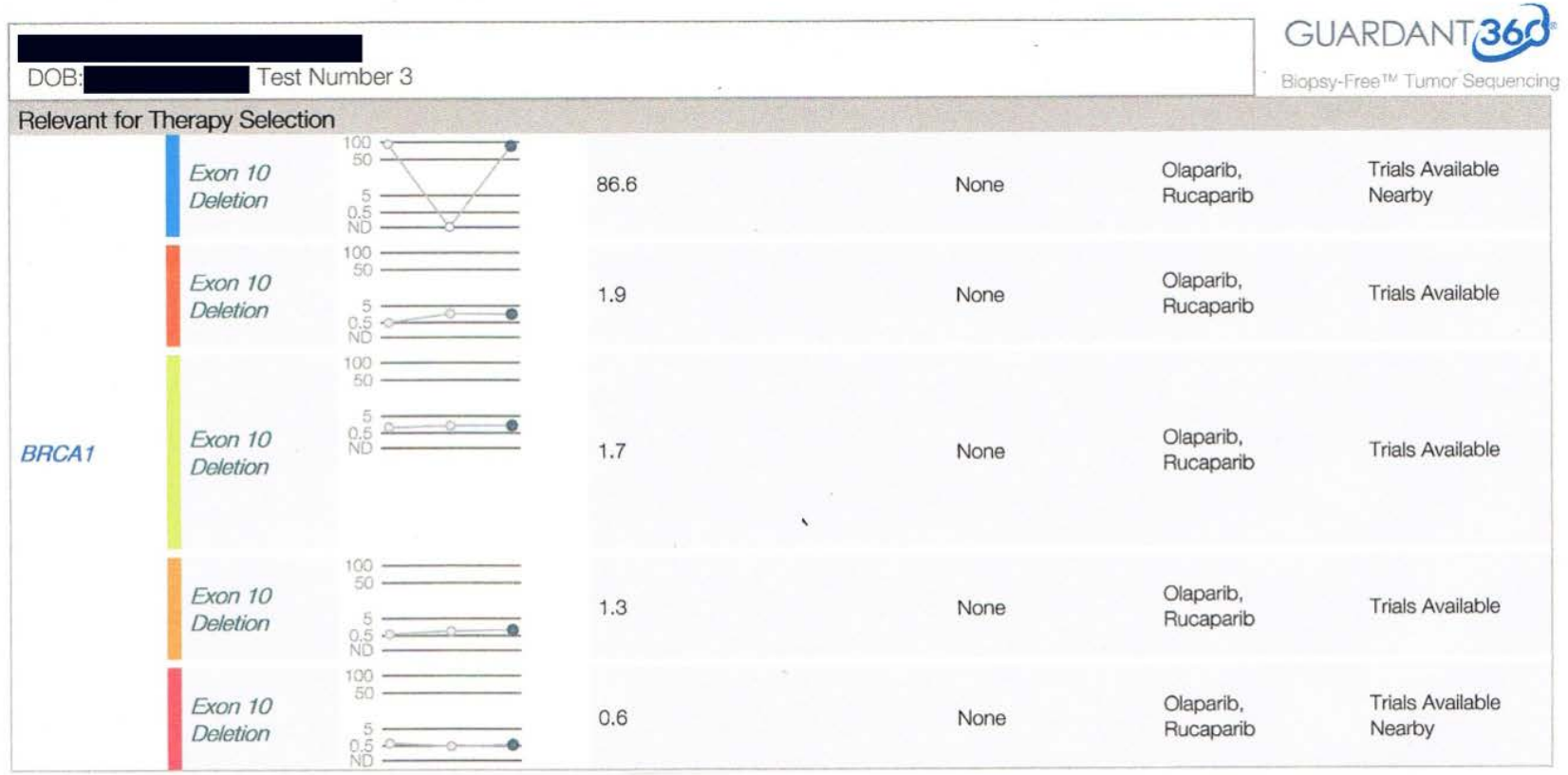

\begin{tabular}{|c|c|c|c|c|c|c|}
\hline TP53 & $\begin{array}{l}\text { Exon } 4 \\
\text { Deletion }\end{array}$ & $\begin{array}{r}100=0 \\
50= \\
0.5 \\
=\end{array}$ & 71.6 & None & None & $\begin{array}{l}\text { Trials Available } \\
\text { Nearby }\end{array}$ \\
\hline MET & $A M P$ & ND & ++ & None & $\begin{array}{l}\text { Cabozantinib, } \\
\text { Crizotinib }\end{array}$ & $\begin{array}{l}\text { Trials Available } \\
\text { Nearby }\end{array}$ \\
\hline FGFR1 & AMP & $\mathrm{ND}=$ & +++ & None & $\begin{array}{l}\text { Lenvatinib, } \\
\text { Nintedanib, } \\
\text { Pazopanib, } \\
\text { Ponatinib, } \\
\text { Regorafenib }\end{array}$ & $\begin{array}{l}\text { Trials Available } \\
\text { Nearby }\end{array}$ \\
\hline MYC & AMP & $\mathrm{ND}^{+}$ & ++ & None & None & $\begin{array}{l}\text { Trials Available } \\
\text { Nearby }\end{array}$ \\
\hline EGFR & AMP & ${ }_{\mathrm{ND}}^{++}=$ & ++ & None & $\begin{array}{l}\text { Afatinib, } \\
\text { Cetuximab, } \\
\text { Erlotinib, } \\
\text { Gefitinib, } \\
\text { Panitumumab }\end{array}$ & $\begin{array}{l}\text { Trials Available } \\
\text { Nearby }\end{array}$ \\
\hline CCNE1 & AMP & $\mathrm{ND}^{+1}$ & ++ & None & None & Trials Available \\
\hline RAF1 & AMP & ND & ++ & None & $\begin{array}{l}\text { Cobimetinib, } \\
\text { Regorafenib, } \\
\text { Sorafenib, } \\
\text { Trametinib }\end{array}$ & $\begin{array}{l}\text { Trials Available } \\
\text { Nearby }\end{array}$ \\
\hline CDK6 & $A M P$ & $\begin{array}{l}{ }_{+++}^{+\infty} \\
\mathrm{ND}^{++\infty}\end{array}$ & ++ & Palbociclib & None & $\begin{array}{l}\text { Trials Available } \\
\text { Nearby }\end{array}$ \\
\hline
\end{tabular}

\begin{tabular}{|llll} 
Additional Alterations & The functional consequences and clinical significance of this gene variant are not \\
TERT & 0.7 & $\begin{array}{l}\text { established. Similar to other alterations in circulating cfDNA, the amount } \\
\text { this variant may reflect disease progression or response to treatment; clinical } \\
\text { correlation is advised. }\end{array}$
\end{tabular}

For a more detailed Guardant360 Patient Report, log onto: https://portal.guardanthealth.com or to set up an account, contact Client Services: 855.698 .8887 Arthur Baca, MD PhD Laboratory Director | CLIA ID: 05D2070300 | 505 Penobscot Drive, Redwood City, CA $94063 \quad$ TST-PRT-001 V15.0 | Pg 2 of 43

Figure 3. Circulating DNA (12/20/2016). 


\section{Conflicts of Interest}

The authors declare no conflicts of interest regarding the publication of this paper.

\section{References}

[1] Veliparib Falls Short in Phase III NSCLC, TNBC Trials (2017)

http://www.onclive.com/web-exclusives/veliparib-falls-short-in-phase-iii-nsclc-tnbc -trials

[2] Dziadkowiec, K.N., Gąsiorowska, E., Nowak-Markwitz, E. and Jankowska, A. (2016) PARP Inhibitors: Review of Mechanisms of Action and BRCA1/2 Mutation Targeting. Przeglaąd Menopauzalny/Menopause Review, 15, 215-219. https://doi.org/10.5114/pm.2016.65667

[3] Livraghi, L. and Garber, J.E. (2015) PARP Inhibitors in the Management of Breast Cancer: Current Data and Future Prospects. BMC Medicine, 13, 188.

https://doi.org/10.1186/s12916-015-0425-1

[4] Oshaughnessy, J., Schwartzberg, L., Danso, M.A., Miller, K.D., Rugo, H.S., et al. (2014) Phase III Study of Iniparib Plus Gemcitabine and Carboplatin Versus Gemcitabine and Carboplatin in Patients with Metastatic Triple-Negative Breast Cancer. Journal of Clinical Oncology, 32, 3840-3847.

https://doi.org/10.1200/jco.2014.55.2984

[5] Muvarak, N.E., Chowdhury, K., Xia, L.M., Lapidus, R.G., Baylin, S.B. and Rassool, F.V. (2016) Enhancing the Cytotoxic Effects of PARP Inhibitors with DNA Demethylating Agents: A Potential Therapy for Cancer. Cancer Cell, 30, 637-650. https://doi.org/10.1016/j.ccell.2016.09.002

[6] Han, H.S., Diéras, V., Robson, M., et al. (2016) Efficacy and Tolerability of Veliparib (V; ABT-888) in Combination with Carboplatin (C) and Paclitaxel (P) vs. Placebo (Plc) $+\mathrm{C} / \mathrm{P}$ in Patients (pts) with BRCA1 or BRCA2 Mutations and Metastatic Breast Cancer: A Randomized, Phase 2 Study. 2016 San Antonio Breast Cancer Symposium, San Antonio, TX, 6-10 December 2016, Abstract S2-05. 